\title{
Source Rocks Characterization of Agbada and Akata Formations in the Niger Delta, Nigeria
}

\author{
Kouadio K. Eugene, Abrakasa Selegha, Ikiensikimama S. Sunday, Botwe Takyi
}

\section{ABSTRACT}

\begin{abstract}
The geochemical analysis was performed on twelve (12) core samples from 6 wells of different formations (Akata, Agbada, and Akata/Agbada) of the onshore Niger Delta Basin. The study was essentially based on the results of the Rock-Eval 6 Pyrolysis to evaluate organic matter abundance, quality, and thermal maturity. The Total Organic Carbon (TOC) varies between 0.6 and $3.06 \mathrm{wt} \%$ and the Hydrogen Index (IH) of the studied samples ranges from 38 to $202 \mathrm{mgHC} / \mathrm{g}$ TOC, indicating predominantly Type III (gas prone) and mixed type II/III (gas and oilprone) kerogen. This suggests terrigenous and a mixture of marine and terrigenous organic matter deposited in a paralic marine setting. The organic matter is immature to early mature according to the thermal maturity parameter $(414<\mathrm{Tmax}<432)$. The well Isan 9 from Agbada $(6760 \mathrm{ft})$ and Agbada/Akata $(8680 \mathrm{ft})$ shows petroleum generation potential of fair $(2,5<\mathrm{S} 2<5 \mathrm{mg} \mathrm{HC} / \mathrm{g}$ rock $)$ to $\operatorname{good}(5<\mathrm{S} 2<10 \mathrm{mgHC} / \mathrm{g}$ rock) and poor for the other wells. The maturation of the kerogen indicates a very early stage of maturation $\left(T_{\max }=432^{\circ} \mathrm{C}\right)$. The results indicate that the shales from Agbada and the transition zone between the upper and lower parts of the Akata Shales are more shaly and perhaps the more mature part of the Agbada formation can be the potential source rocks of Niger Delta Basin.
\end{abstract}

Keywords: Characterization, Niger Delta Basin, Rock-Eval, source rocks.

\author{
Published Online: July 22, 2020 \\ ISSN: $2684-446 \mathrm{X}$ \\ DOI : $10.24018 /$ ejgeo.2020.1.4.38 \\ K. E. Kouadio* \\ Institut National Polytechnique Felix \\ Houphouët-Boigny, Yamoussoukro, \\ Côte d'Ivoire. \\ World Bank African Centre of \\ Excellence, Centre for Oilfield \\ Chemicals Research, University of Port \\ Harcourt, Nigeria \\ (e-mail: eugene.kouadio2@inphb.ci) \\ S. Abrakasa \\ Department of Geology, University of \\ Port Harcourt, Rivers State, Nigeria \\ (e-mail: s.abrakasa@outlook.com) \\ S. S. Ikiensikimama \\ Department of Petroleum Engineering, \\ University of Port Harcourt, Rivers \\ State, Nigeria. \\ (e-mail: \\ sunday.ikiensikimama@uniport.edu.ng) \\ T. Botwe \\ World Bank African Centre of \\ Excellence, Centre for Oilfield \\ Chemicals Research, University of Port \\ Harcourt, Nigeria. \\ (e-mail: geokbotwe@gmail.com)
}

*Corresponding Author

\section{INTRODUCTION}

Whatever the twist and turn of the global energy context are, our needs for hydrocarbons are constantly increasing and will continue to grow at a sustained rate for many years due to the dynamism of economic growth, which allows the populations of emerging countries to equip with energyconsuming goods. As the cost of oil exploration becomes increasingly expensive, the petroleum industry is looking at reducing exploration risk. And one way of doing this is to understand the hydrocarbon potential of source rocks. In the Niger Delta, a variety of studies have been carried out to determine the location and effectiveness of the region's source rocks [1]-[2]. Based on organic-matter content and type, [3] Evamy et al. (1978) proposed that both the marine shale (Akata Formation) and the shale interbedded with paralic sandstone (lower Agbada Formation) were the source rocks for the Niger Delta oils. The Akata shale is at least volumetrically sufficient to generate enough oil for a worldclass oil province such as the Niger Delta.

According to [3]-[4], the Agbada Formation has intervals that contain sufficient organic carbon to have source rock potential. Despite these in-depth studies, no consensus has yet emerged regarding the true identity of the petroleum system (s) that have contributed to the large Niger Delta oil fields [5]. This controversy arose because of the difficulty of locating source intervals convincing enough to have given rise to large volumes of oil trapped in the reservoirs.

According to [6], the key element from a petroleum geochemistry point of view is the source rocks, rocks from which petroleum has been generated, or is capable of being generated. Incomplete, inconsistent, and sometimes controversial results from Niger Delta basin studies do not assure the quality, maturity, and true petroleum potential of source rocks. This study aims to re-evaluate the source rocks of Agbada and Akata formations by Rock-Eval 6 analysis.

\section{STUDY AREA}

The Niger Delta is one of the most prolific petroleum provinces in the world, it is located in the Southern Nigeria margin of the Gulf of Guinea., with latitude $4^{\circ} 49^{\prime} \mathrm{N}$ and 
longitude $6^{\circ} 0$ ' E [7]. The Niger Delta sedimentary basin covers an area of about $256,000 \mathrm{~km} 2$ [8]. It is bounded to the south by the Gulf of Guinea and the north by older tectonic elements (Cretaceous) including the Anambra Basin, the Abakaliki uprising and the Afikpo syncline, and to the east and west by the Cameroon volcanic line and the Dahomey basin respectively (Fig. 1). The Niger Delta basin began to form in the Cretaceous when the African plate separated from the South American plate; the basin is delimited by rift faults on its northwest and northeast edges [9].

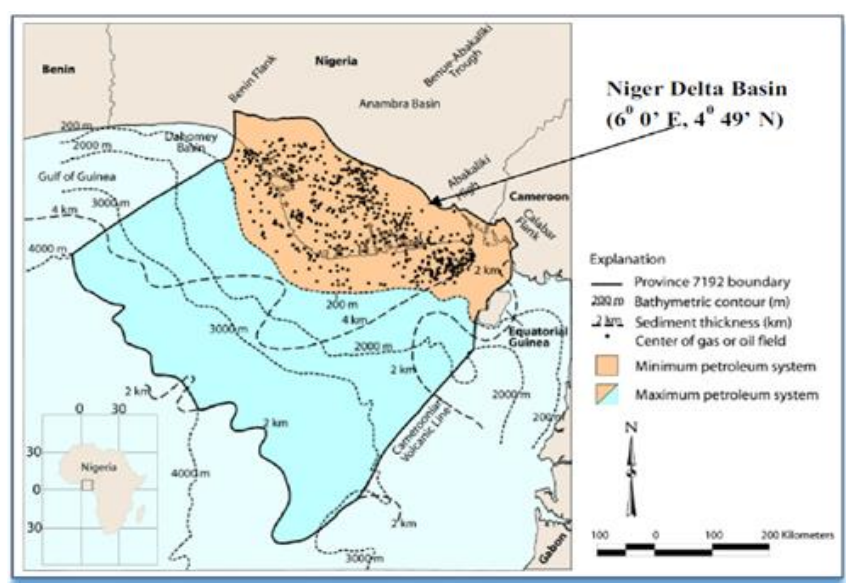

Fig. 1. Map of Nigeria showing the Niger Delta Basin. (Source: From USGS Open File Rpt No. 99-501).

After the rifting, gravity tectonics became the main deformation process [4]. Pre- and syn-sedimentary tectonics described by [10]-[11] characterised the evolution of the Niger Delta basin. The regressive clastic sequence in the Niger Delta began to form in the Paleocene and has since formed sediments which now reachs a thickness of 12,000 m [10]. The Niger Delta Basin (Fig. 2) consists of three main lithostratigraphic units of Cretaceous to Holocene origin. These units represent the prograding depositional environments which are distinguished mainly based on shalesand ratios and are continental, transitional, and marine environment [12]. This Tertiary sequence in the Niger Delta consists of the three formations that are locally designated in ascending order (from the bottom) the Akata Formation, Agbada Formation, and Benin Formation [4]-[13].

At the base of the system is the Akata Formation, a sequence of planktonic foraminifera-rich non- compacted transgressive Paleocene-to-Holocene marine shale, clays, and silt. The Akata formation at the base of the delta is of marine origin and consists of sequences of thick shale (potential source rock), turbiditic sand (potential deepwater reservoirs), and small amounts of clay and silt. The Paleocene and the recent Akata formations were formed during the lowlands when terrestrial organic matter and clays were transported to deep water areas characterized by low energy conditions and a deficiency in oxygen [14]. It is estimated that the formation can reach 7,000 meters thick [7]. The Akata Formation is covered by more than $4,000 \mathrm{~m}$ of alternating sandstones and shales of paralic facies [13]-[15]. This interstratified unit of sandstone and shale is called the Agbada Formation (Recent Eocene). The Agbada Formation represents the delta system (delta front, fluvio-deltaic facies) of the sedimentary sequence [4]. The Agbada Formation is overlain by the third formation, the Benin Formation, a last continental deposit from the Eocene to Recent alluvial and upper coastal plains sums up to $2000 \mathrm{~m}$ thick [15].
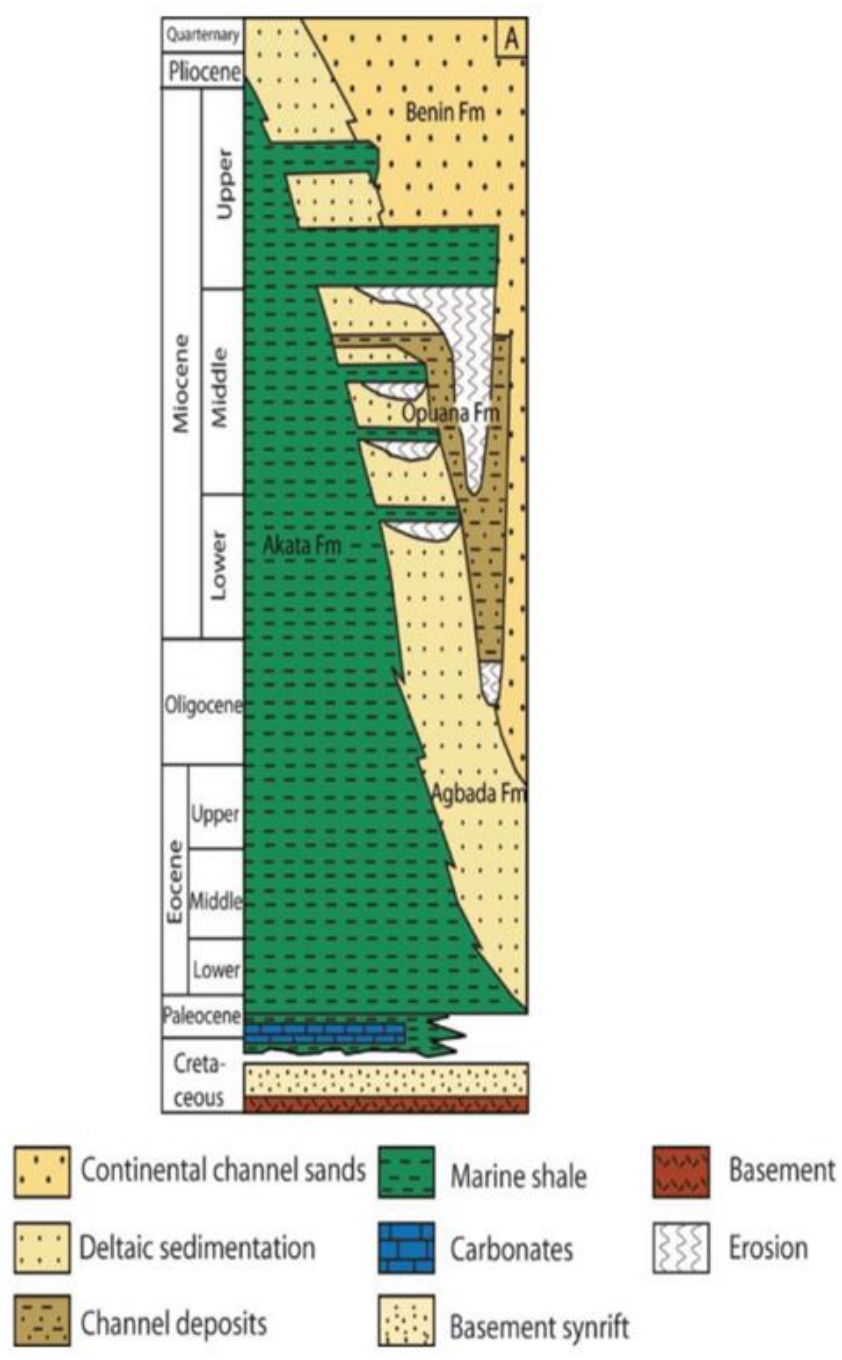

Fig. 2. Stratigraphic column showing the three formations of the Niger Delta (After [12])

This study is based on six (6) different wells located in the onshore part of the Niger Delta basin (Fig. 3).

\section{MAterials AND MethodS}

Twelve (12) core samples were recovered from six (6) exploration wells located in the onshore part of the Niger Delta Basin. The sample locations are shown in Fig. 3. The samples geological formation provenance and depth details are summarized in Table I. The samples were analysed at the PETROCI Analysis and Research Center in Abidjan (Côte d'Ivoire). Approximately 50-100 g of the core sample was collected. Then, the samples were ground into a fine powder for Rock-Eval analysis. The analyses were performed on the 12 samples by using Rock-Eval 6 instrument, according to the procedure of Espitalié et al. [16]. The method consisted in estimating petroleum potential of rock samples by pyrolysis according to a programmed temperature pattern $\left(300^{\circ} \mathrm{C}<\mathrm{T}<650^{\circ} \mathrm{C}\right)$. Released hydrocarbons are monitored by a FID (Flame ionization Detector), forming the peaks S1 (thermo-vaporized free hydrocarbons) and S2 (hydrocarbons from cracking of organic matter). In addition, $\mathrm{CO}$ and $\mathrm{CO}_{2}$ released during pyrolysis is monitored in real time by mean 
of an IR cell, giving information on the oxidation state of organic matter. The method is completed by oxidation of the rock sample according to a programmed temperature pattern $\left(300^{\circ} \mathrm{C}<\mathrm{T}<850^{\circ} \mathrm{C}\right)$. Released $\mathrm{CO}$ and $\mathrm{CO} 2$ are monitored in real time by mean of an IR cell. This complementary stage allows determination of Total Organic Carbon and MINeral Carbon content of samples.

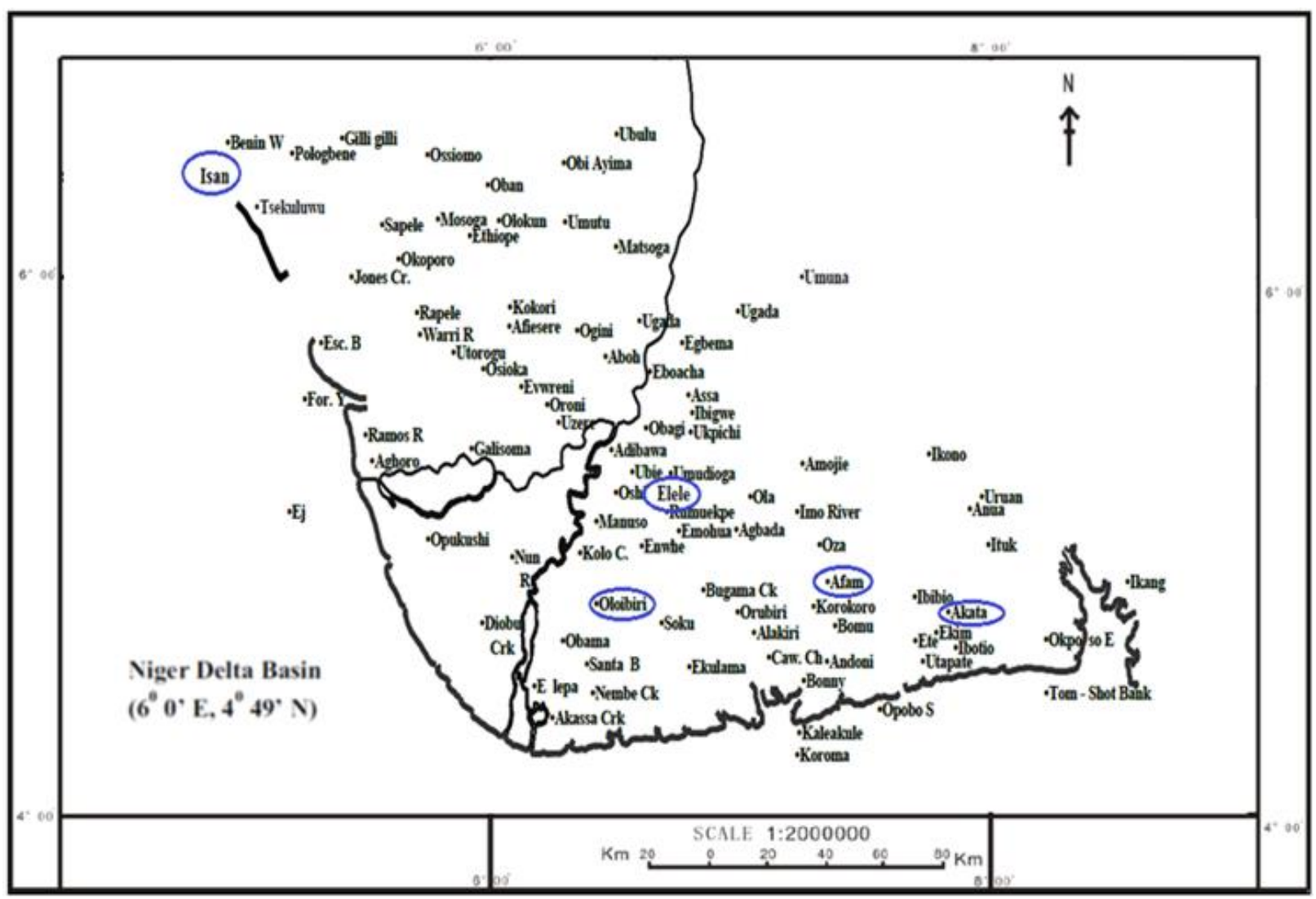

Fig. 3. Location map of Niger Delta Basin showing the six (6) exploratory wells.

TABLE I: TABLE SHOWING THE SAMPLE DETAILS

\begin{tabular}{|c|c|c|}
\hline Wells & Formations & Depth (ft) \\
\hline Akata 2 & Agbada & 6541 \\
\hline Akata 2 & Agbada/Akata & 7460 \\
\hline Akata 2 & Akata & 8062 \\
\hline Afam I & Agbada & 6830 \\
\hline Afam I & Akata & 10200 \\
\hline Akata 7 & Agbada & 7100 \\
\hline Akata 7 & Agbada/Akata & 7690 \\
\hline Isan 9 & Agbada & 6760 \\
\hline Isan 9 & Agbada/Akata & 8680 \\
\hline Elele I & Akata & 8760 \\
\hline Olobiri 1 & Agbada & 7170 \\
\hline Olobiri 1 & Akata & 10600 \\
\hline
\end{tabular}

During the analysis, ion fluxes are emitted during the temperature rise. These flows are recovered and quantified. Four parameters can thus be determined:

- S1: characterizes the amount of free hydrocarbon (in the form of gas or oil) contained in the sample. It is expressed in $\mathrm{mgHC} / \mathrm{g}$ rock. The amount of free hydrocarbon is generally significant and is of interest when $\mathrm{S} 1>1 \mathrm{mgHC} / \mathrm{g}$ of rock;

- S2: hydrocarbon produced during the cracking of nonextractable organic matter (kerogen). This parameter is therefore an evaluation of the quantity of gas and oil likely to be produced during the evolution of this rock. It is expressed in $\mathrm{mgHC} / \mathrm{g}$ rock;

- S3: amount of $\mathrm{CO} 2$ resulting from the cracking of kerogen, which is expressed in $\mathrm{mgCO} 2 / \mathrm{g}$ rock;

- $\mathrm{T}_{\max }$ : maximum temperature of hydrocarbon production (top of peak S2). It characterizes the thermal maturity of the rock. It depends on the nature of the kerogen (and therefore on the type of Organic Matter) and on its degree of diagenetic evolution. This parameter is only credible if S2 is greater than $0.2 \mathrm{mgHC} / \mathrm{g}$ rock [17].

These determined parameters make it possible to calculate five (5) additional parameters which are:

- TOC (Total Organic Carbon): expressed as a percentage by weight of the total rock (\% by weight), it allows the petroleum potential of the source rock to be determined. Tissot and Welte [18] defined the minimum quantity of TOC that carbonates and shales must contain to be qualified as source rock. These quantities are respectively $0.3 \%$ and $0.5 \%$ by weight. The $\mathrm{S} 2$ is more realistic than the TOC for the estimation of petroleum potential because the TOC includes inert carbons which are incapable of generating hydrocarbons [19];

- IH (Hydrogen Index): it corresponds to the degree of aliphaticity of organic matter, expressed in $\mathrm{mgHC} / \mathrm{g}$ TOC (S2 $\mathrm{x} 100$ / TOC). It allows to determine the type of organic matter present;

- IO (Oxygen Index): it corresponds to the degree of oxidation of organic matter and is expressed in $\mathrm{mgCO} 2 / \mathrm{g}$ TOC (S3 x 100 / TOC). The S3 is not too reliable like the 
other parameters of the Rock-Eval 6 because of the presence of carbonate minerals or kerogens oxidized as a result of spraying the samples [19]. It is therefore advisable to use the

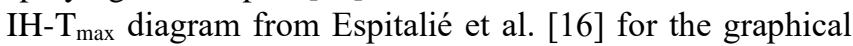
determination of the type of organic matter. Plot of HI versus OI can be used to deduce the type of organic matter present in the source rock [20]. The IH and IO indices are respectively a good approximation of the $\mathrm{H} / \mathrm{C}$ and $\mathrm{O} / \mathrm{C}$ ratios of the Organic Matter. They can be classified in the Van Krevelen diagrams used to characterize the origin of organic matter. The Rock-Eval 6 interpretation software (Rock int) automatically plots the IH-T $\mathrm{T}_{\max }$ diagram.

- IP = S2 / (S1 + S2): it corresponds to the production index which characterizes the evolution of organic matter. The Tmax and IP parameters are used to characterize thermal maturity;

- $\mathrm{PP}=\mathrm{S} 1+\mathrm{S} 2$ : is the genetic potential of the source rock. The genetic potential of the source rock is defined as the total amount of oil and gas that unit quantity of the source rock could produce if the rock were buried deep enough and long enough. According to their classification scheme, rocks with $\mathrm{PP}$ of less than $2 \mathrm{mg} \mathrm{HC/} \mathrm{g} \mathrm{rock} \mathrm{correspond} \mathrm{to} \mathrm{gas-prone}$ rocks or non- generative ones, rocks with PP between 2 and $6 \mathrm{mgHC} / \mathrm{g}$ rock are moderate source rocks with fair gas/oil potential, and those with $\mathrm{PP}$ greater than $6 \mathrm{mgHC} / \mathrm{g}$ rock are good source rocks [18].

To better characterize the Niger Delta source rocks and complete the objectives assigned to this study, we have treated the raw geochemical data, based on the following criteria [21]:
- if $\mathrm{S} 2<0.2$ : IP and $\mathrm{T}_{\max }$ are not significant;

- if COT < 0.3: all the parameters are not significant;

- if TOC < 0.5: IO is not significant.

For the evaluation of source rock according to the standards of IFP and other companies, the data filtering is done, imposing a minimum limit of $0.5 \%$ for the TOC (Total Organic Carbon) and $0.2 \mathrm{mgHC} / \mathrm{g}$ rock for Hydrocarbon products resulting from the cracking of kerogen (S2).

Table II show the guideline for source rocks interpretation developed by Peters and Cassa [22]. The pyrolysis data of the collected samples are confined in Table III.

TABLE II: GUIDELINES FOR INTERPRETING SOURCE ROCK QUANTITY, QUALITY, AND MATURITY ([22], MODIFIED)

\begin{tabular}{|c|c|c|c|c|}
\hline Quantity & TOC & \multicolumn{2}{|c|}{$\mathrm{Sl}$ (mg HC/g rock) } & $\mathrm{S} 2$ (mgHC/g rock) \\
\hline Poor & $<0.5$ & \multicolumn{2}{|c|}{$<0.5$} & $<2.5$ \\
\hline Fair & $0.5-1$ & \multicolumn{2}{|c|}{$0.5-1$} & $2.5-5.0$ \\
\hline Good & $1-2$ & \multicolumn{2}{|c|}{$1-2$} & $5-10$ \\
\hline Very Good & $2-4$ & \multicolumn{2}{|c|}{$2-4$} & $10-20$ \\
\hline Excellent & $>4$ & \multicolumn{2}{|c|}{$>4$} & $>20$ \\
\hline Quality & $\mathrm{HI}(\mathrm{mg} \mathrm{HC} / \mathrm{g} \mathrm{TOC})$ & \multicolumn{2}{|c|}{ S2/S3 } & Kerogen Type \\
\hline None & $<50$ & \multicolumn{2}{|c|}{$<1$} & IV \\
\hline Gas & $50-200$ & \multicolumn{2}{|c|}{$1-5$} & III \\
\hline Gas and oil & $200-300$ & \multicolumn{2}{|c|}{$5-10$} & II/III \\
\hline Oil & $300-600$ & \multicolumn{2}{|c|}{$10-15$} & II \\
\hline \multirow[t]{2}{*}{ Oil } & $>600$ & \multicolumn{2}{|c|}{$>15$} & I \\
\hline & \multicolumn{3}{|c|}{ Maturation } & Generation \\
\hline Maturity & Ro (\%) & $\operatorname{Tmax}\left({ }^{\circ} \mathrm{C}\right)$ & TAI & $\begin{array}{l}\text { Production Index } \\
(\mathrm{S} 1 / \mathrm{s} 1+\mathrm{S} 2)\end{array}$ \\
\hline $\begin{array}{l}\text { Immature } \\
\text { Early }\end{array}$ & $0.2-0.6$ & $<435$ & $1.5-2.6$ & $<0.1$ \\
\hline Mature & $0.6 \cdot 0.65$ & $435-445$ & $2.6-2.7$ & $0.1-15$ \\
\hline Peak Mature & $0.65-0.9$ & $445-450$ & $2.7-2.9$ & $0.25-0.4$ \\
\hline Late Mature & $0.9-1.35$ & $450-470$ & $2.9-3.3$ & $>0.4$ \\
\hline Post Mature & $>1.35$ & $>470$ & $>3.3$ & - \\
\hline
\end{tabular}

TABLE III: RESULT OF ROCK-EVAL ANALYSIS OF STUDIED SAMPLES

\begin{tabular}{|c|c|c|c|c|c|c|c|c|c|c|c|c|}
\hline Wells & Formations & Depth (ft) & TOC "wt\%" & S1 & S2 & S3 & Tmax & HI & OI & IP & IP & $\mathrm{PP}(\mathrm{S} 1+\mathrm{S} 2)$ \\
\hline AKATA 2 & Agbada & 6541 & 0,91 & 0,04 & 0,62 & 1,33 & 424 & 68 & 147 & 0,07 & 0,07 & 0,66 \\
\hline AKATA 2 & Agbad a/Akata & 7460 & 0,95 & 0,06 & 0,38 & 1,2 & 414 & 40 & 125 & 0,14 & 0,14 & 0,44 \\
\hline AKATA 2 & Akata & 8062 & 1,48 & 0,07 & 1,01 & 1,64 & 423 & 68 & 111 & 0,06 & 0,06 & 1,08 \\
\hline AFAM 1 & Agbada & 6830 & 0,92 & 0,03 & 0,6 & 1,53 & 423 & 65 & 166 & 0,05 & 0,05 & 0,63 \\
\hline AFAM 1 & Akata & 10200 & 1,32 & 0,07 & 0,74 & 0,87 & 430 & 56 & 66 & 0,08 & 0,08 & 0,81 \\
\hline AKATA 7 & Agbada & 7100 & 0,85 & 0,04 & 0,62 & 1,43 & 426 & 72 & 168 & 0,06 & 0,06 & 0,66 \\
\hline AKATA 7 & Agbad a/Akata & 7690 & 0,76 & 0,06 & 0,37 & 1,23 & 415 & 49 & 163 & 0,14 & 0,14 & 0,43 \\
\hline ISAN 9 & Agbada & 6760 & 1,81 & 0,8 & 3,47 & 0,97 & 432 & 192 & 54 & 0,19 & 0,19 & 4,27 \\
\hline ISAN 9 & Agbad a/Akata & 8680 & 3,06 & 1,27 & 6,19 & 2,05 & 432 & 202 & 67 & 0,17 & 0,17 & 7,46 \\
\hline ELELE 1 & Akata & 8760 & 1,14 & 0,36 & 1,24 & 1,52 & 424 & 109 & 133 & 0,23 & 0,23 & 1,6 \\
\hline OLOBIRI 1 & Agbada & 7170 & 1,2 & 0,04 & 0,65 & 2,18 & 421 & 54 & 182 & 0,06 & 0,06 & 0,69 \\
\hline OLOBIRI 1 & Akata & 10600 & 0,6 & 0,02 & 0,23 & 1,28 & 418 & 38 & 214 & 0,1 & 0,1 & 0,25 \\
\hline
\end{tabular}

\section{RESUlts AND Discussion}

\section{A. Source Rock Richness and Generation Potential}

The Total Organic Carbon (TOC) expressed as a percentage by weight of the total rock (\% by weight), it allows the petroleum potential of the source rock to be determined. Tissot and Welte [18] defined the minimum quantity of TOC that carbonates and shales must contain to be qualified as source rock. The S2 is hydrocarbon produced during the cracking of non-extractable organic matter (kerogen). This parameter is therefore an evaluation of the quantity of gas and oil likely to be produced during the evolution of this rock. It is expressed in $\mathrm{mgHC} / \mathrm{g}$ rock.

Based on the criteria developed by Peters and Cassa [22], the TOC (wt\%) of the samples collected in the six (6) wells of the Niger delta basin varies between 0.6 and $3.06 \mathrm{wt} \%$ (Table III). All the samples have a TOC greater than $0.5 \mathrm{wt} \%$. This suggests that these samples correspond to potential source rocks with a richness in organic matter varying from fair to very good. The well Isan 9 samples from the Agbada and Akata/Agbada formations appear to have the best qualities of source drocks, with TOC of 1.81 and $3.6 \mathrm{wt} \%$ respectively. The $\mathrm{S} 2$ values of most of the samples analyzed are less than $2.5 \mathrm{mgHC} / \mathrm{g}$ rock (Fig. 4). This shows the poor petroleum potential of these samples. On the other hand, the samples from the well Isan 9 have a petroleum potential varying from fair (3.75 $\mathrm{mgHC} / \mathrm{g}$ rock for Agbada) to good (6.19 $\mathrm{mgHC} / \mathrm{g}$ rock for Akata / Agbada). The cross plot of S2 versus TOC (Fig. 5) shows that the pyrolysis $\mathrm{S} 2$ yields lie in a range of 0.23 to $6.19 \mathrm{mgHC} / \mathrm{g}$ rock. Therefore, based on pyrolysis $\mathrm{S} 2$ yields and TOC, the analyzed sediments can be 
considered as poor to good potential source rocks for the generation of hydrocarbon. Agbada and Akata/Agbada facies from well Isan 9 can be considered as potential source rocks for the hydrocarbon generation in the Niger Delta Basin.

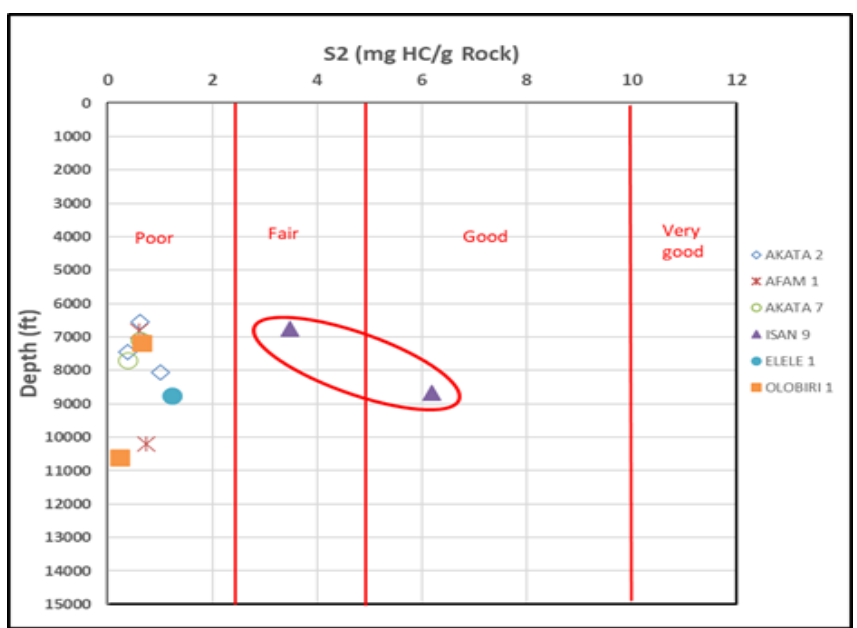

Fig. 4. Pyrolysis S2 versus depth plot showing S2 variation with depth.

\section{B. Type of Organic Matter}

Determination of the type of organic matter is necessary. It allows to have a general idea on the petroleum potential of the source rock on the one hand and its origin on the other hand, for this we mainly use, the IH-IO and IH-Tmax diagrams established from the indexes of hydrogen (IH) and oxygen (IO), and the values of Tmax [23]. IH (Hydrogen Index) corresponds to the degree of aliphaticity of organic matter, expressed in $\mathrm{mgHC} / \mathrm{g}$ TOC (S2 x $100 /$ TOC). It allows to determine the type of organic matter present. The Rock-Eval 6 interpretation software (Rock int) automatically plots the IH-Tmax diagram. Oxygen Index (IO) corresponds to the degree of oxidation of organic matter and is expressed in $\mathrm{mg} \mathrm{CO} 2$ / g TOC (S3 x 100 / TOC).

The hydrogen index $(\mathrm{IH})$ values of the samples studied are between 38 et $202 \mathrm{mgHC} / \mathrm{g}$ TOC (Table 3). Most of the samples analysed have HI values of $50-200 \mathrm{mgHC} / \mathrm{g}$ TOC, which indicate gas prone kerogen Type III. Two (2) samples from well Isan 9 show the mixed kerogen Type II/III which has the potential to yield oil and/or gas. The modified Van Krevelen diagram (HI versus OI) (Fig. 5) shows that almost all the samples from the three (3) exploratory wells consist predominantly of Types III and II/III kerogens, which are capable of generating gas and gas-oil respectively at a suitable temperature at depth. The Type II/III describes a transitional composition between types II and III that represents a mixture of marine and terrigenous organic matter deposited in a paralic marine setting and Type III Kerogen originates from terrigenous plants. The samples from well Akata $2(7460 \mathrm{ft})$, Akata $7(7690 \mathrm{ft})$ from Akata/Agbada formation, and Olobiri (10 $600 \mathrm{ft}$ ) from Akata formation, indicate Type IV kerogen which generates neither oil nor gas.

The same results have been obtained by several authors such as Nwachukwu and Chukwura [23]; Ekweozor and Daukoru [2]; Magoon and Valin [24]; Asadu et al. [25].

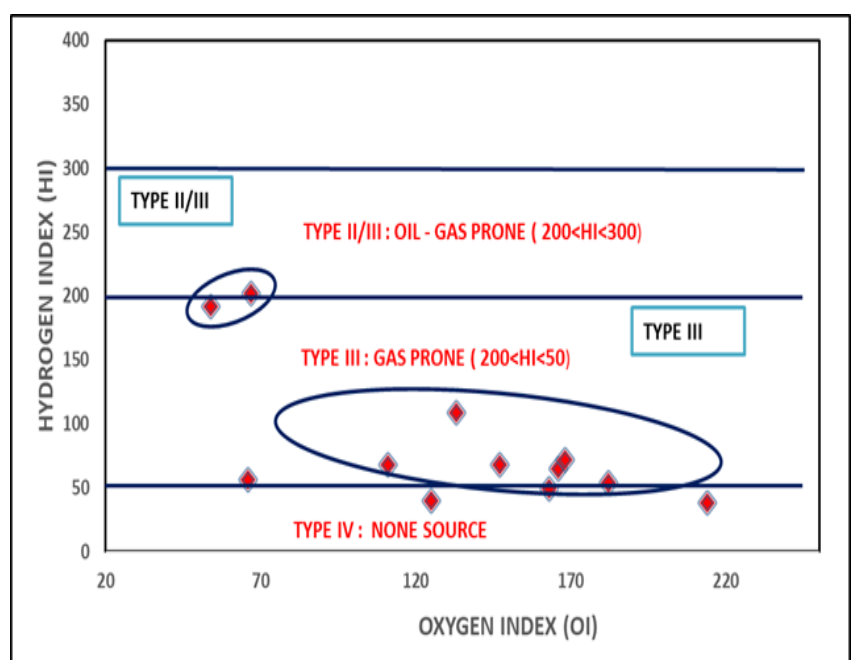

Fig. 5. Modified Van Krevelen diagram showing the organic matter types of the studied samples.

\section{Thermal maturation}

As a rock containing kerogen and is progressively buried in a subsiding basin, it is subjected to increasing pressure and temperature. A source rock is defined as mature when it is reached to generate hydrocarbons. A rock that does not reach to the level of generation of hydrocarbons is defined as an immature source, and that which passed the time of significant generation and expulsion, it is considered as overmature source rock. The pyrolysis Tmax is the maximum temperature of hydrocarbon production (top of peak S2). It characterizes the thermal maturity of the rock. It depends on the nature of the kerogen (and therefore on the type of Organic Matter) and on its degree of diagenetic evolution. This parameter is only credible if $\mathrm{S} 2$ is greater than 0.2 $\mathrm{mgHC} / \mathrm{g}$ rock [17].

The maturity of the twelve (12) samples of Niger Delta Formations has been investigated by plotting the results in HI versus Tmax diagram (Fig. 6). The pyrolysis Tmax values for the most of studied samples range from $420^{\circ} \mathrm{C}$ to $430^{\circ} \mathrm{C}$, indicating an Immature organic matter. Only Afam 1 sample from Akata formation and Isan 9 samples with Agbada and Akata/Agbada facies show respectively $430^{\circ} \mathrm{C}$ and $432^{\circ} \mathrm{C}$ as Tmax values. These values indicate early mature source rocks. The recent studies of Ogbesejana et al. [26] confirm these results.

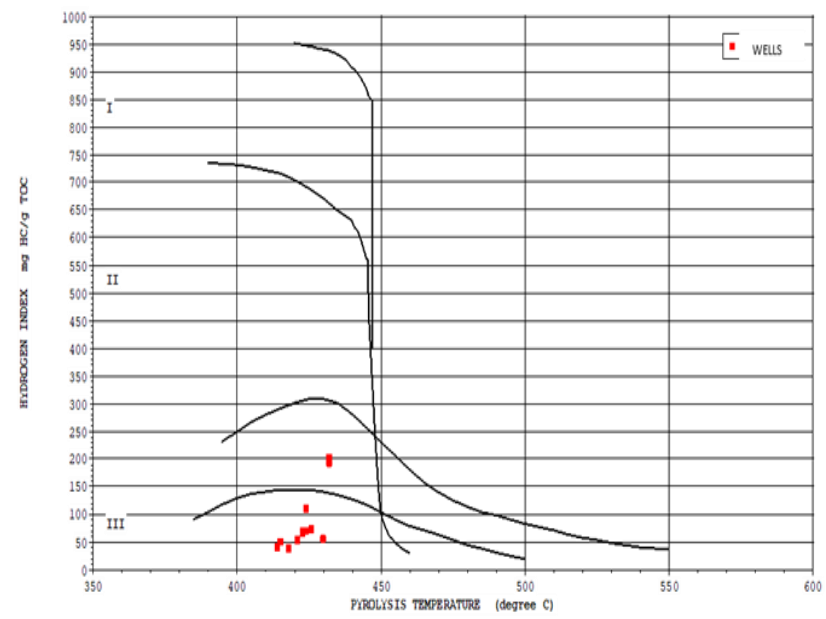

Fig. 6. Plot of hydrogen index (HI) versus Tmax for the samples analyzed, showing kerogen quality and thermal maturity stages. 


\section{Hydrocarbon generative potential and production index}

The studied samples have a fair to good generative potential, with two (2) samples (well Isan 9) showing Very good generative potential (Fig. 7). This is supported by the presence of Type II/III and type III kerogens even though few Type IV kerogens are present. The good to very good generative potential of samples in Well Isan 9 is supported by the presence of type II/III with oil and gas prone. Most of samples show poor Petroleum Potential PP $<2 \mathrm{mgHC} / \mathrm{g}$ rock. Only the samples from the well Isan 9 (Agbada and Akata/Agbada formations) show the values ranging between $2<\mathrm{PP}<6 \mathrm{mgHC} / \mathrm{g}$ rock. This range of values indicates Fair to Good petroleum genetic potential (Fig. 8). Figure 9 shows the cross plot of the Production index (PI) versus Tmax. Most of the samples in studied wells have Tmax $<435^{\circ} \mathrm{C}$ and $\mathrm{PI}<$ 0.1 . Thereby making them thermally immature and indigenous. Most of the samples have $0.1<\mathrm{PI}<0.4$, indicating early mature source rocks (oil windows). Most of the samples are non-indigenous except for two samples from Well Isan 9 which fall within the hydrocarbon generation zone. It has been strongly suggested that the most probable source material is located in the transition zone between the upper and lower parts of the Akata Shales as well as the more shaly, and maybe more mature part of the Agbada Formation. It is noteworthy that the characteristics of the Akata and those of the Agbada Shales from the transitional zone (Agbada/Akata) do not differ significantly. The results of this study support the findings of Adegoke et al. [8].

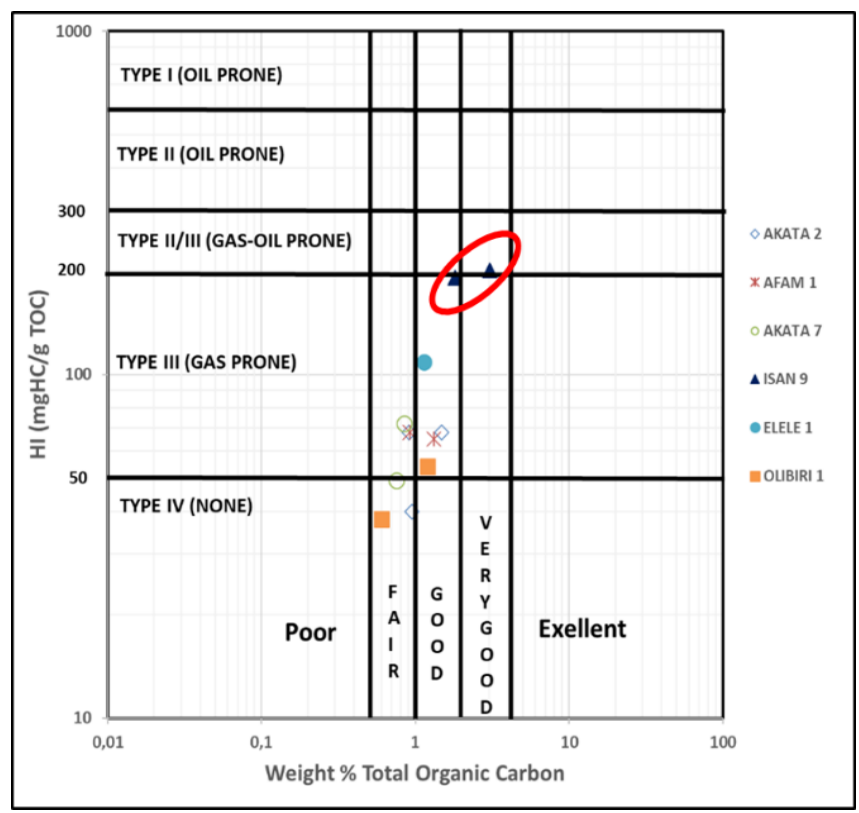

Fig. 7. Plot of hydrogen index (HI) versus TOC.

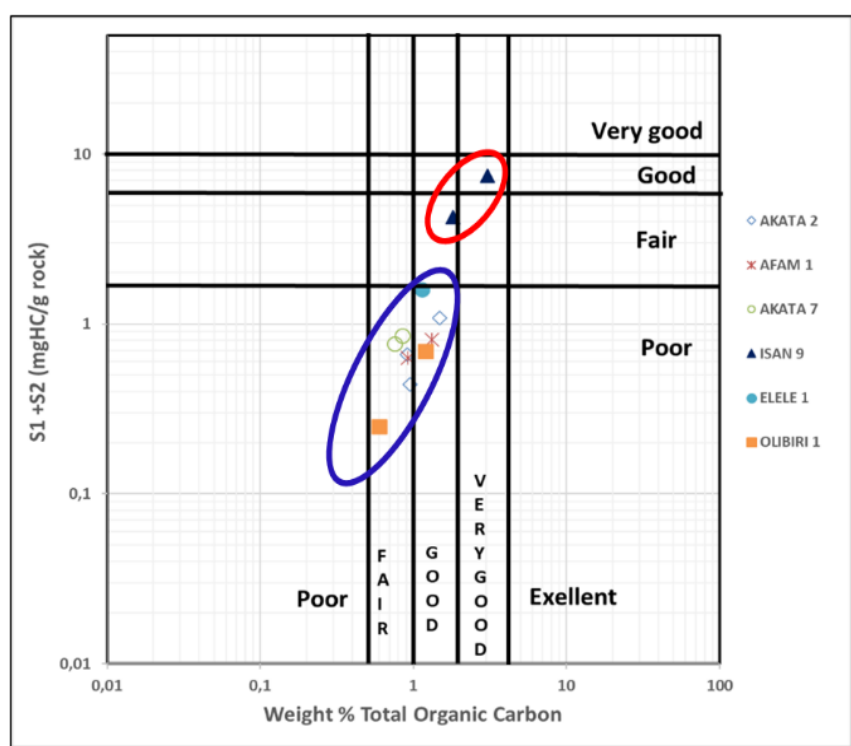

Fig. 8. Plot of Petroleum potential (PP) versus TOC.

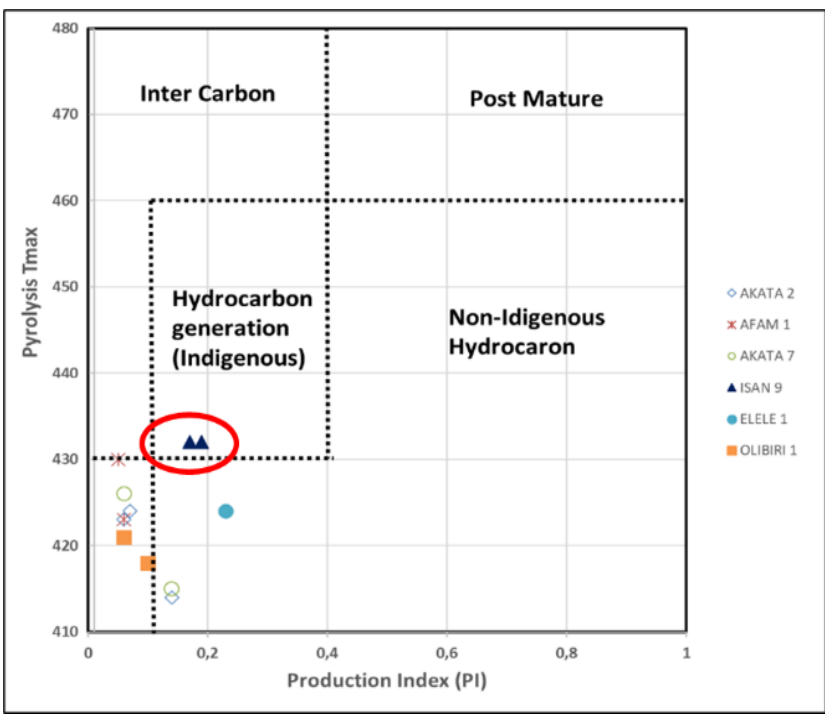

Fig. 9. Plot of Production index (PI) versus Tmax.

\section{CONCLUSION}

Most of the analysed samples have poor petroleum generative potential despite the good values of TOC (Fair to Very Good) except for two samples from the Well Isan 9. The studied samples define Type III and Type II/III kerogens for the Niger Delta Basin. Most of the samples studied are thermally immature except for three (3) samples, one (1) from well Afam 1 (Akata/10200 ft) and two (2) from well Isan 9 (Akata/Agbada, Agbada) which show early maturity and fall within the hydrocarbon generation zone. Based on this study, the shales from Agbada and the transition zone between the upper and lower parts of the Akata and the more shaly, and perhaps more mature part of the Agbada formation (Agbada/Akata) can be the potential source rocks of Niger Delta Basin. Visual kerogen and biomarkers analysis are recommended to confirm the maturity and source input of the organic matter.

\section{ACKNOWLEDGMENT}

The authors are grateful to Dr Pascal KOUADIO for his valuable support in my studies, to PETROCI Analysis and Research Center in Abidjan (Côte d'Ivoire), especially to Mrs 
Laure ATSE for the analysis of the samples. We also thank the General Director of Institut National Polytechnique Felix Houphouet-Boigny, Yamoussoukro (Côte d'Ivoire) and the African Centre of Excellence, Centre for Oilfield Chemicals Research, University of Port Harcourt, Nigeria for the research support.

\section{REFERENCES}

[1] Knox, G.J., and Omatsola, E.M. (1989). Development of the Cenozoic Niger Delta in terms of the 'Escalator Regression' model and impact on hydrocarbon distribution. In: van der Linden, W.J.M., Cloetingh, S.A.P.L., Kaasschieter, P.K., vander Graff, W. J E., Vandenberghe, J. \& van der Gun, J.A.M. (eds.), proceedings of the KNGMG Symposiums on Coastal Lowlands, Geology and Geotechnology. Kluwer Academic Publishers, Amsterdam, pp. 181-202.

[2] Ekweozor, C.M., and Daukoru, E.M. (1994). Northern delta depobelt portion of the Akata- Agbada petroleum system, Niger Delta, Nigeria. In: Magoon, B., Dow, W.G. (Eds.), The Petroleum System-from Source to Trap, vol. 60. American Association of Petroleum Geologists Memoir, pp. 599-614.

[3] Ekweozor, C.M., and Okoye. N.V. (1980). Petroleum source-bed evaluation of Tertiary Niger Delta: American Association of Petroleum Geologists Bulletin, v. 64, 1251-1259.

[4] Tuttle, M.L.W., Charpentier, R.R., and Brownfield, M.E. (1999).Tertiary Niger Delta (Akata-Agbada) Petroleum System (No. 719201), Niger Delta Province, Nigeria, Cameroon, and Equatorial Guinea, Africa . A U.S Geological Survey World Ener AssessmentProject:http://greenwood.cr.usgs.gov/energy/WorldEnergy /OF9950HlChapterA.htrnl \#TOP. Date accessed: 20/111 2005.

[5] Eneogwe, C., and Ekundayo, O. (2003). Geochemical correlation of crude oils in the NW Niger Delta, Nigeria. Journal of Petroleum Geology 26, 95-103.

[6] Dembicki-Jr., H. (2017). Practical petroleum geochemistry for exploration and productions. Elsevier, 341pp. https://doi.org/10.1016/j.jhsb.2006.10.005

[7] Doust, B., and Omatsola, E. (1990). Niger Delta, in, Edwards, J. D. and Santogrossi, P.A., eds., Divergent/passive Margin Basins., AAPG Memoir 48 : Tulsa, American Association of Petroleum Geologists. 239-248.

[8] Adegoke, O.S., Oyebamiji, A.S., Edet, J.J., Osterloff, P.L., and Ulu, O.K. (2017). Cenozoic Foraminifera and Calcareous Nannofossil Biostratigraphy of the Niger Delta. Elsevier, 592.

[9] Whiteman, A. J. (1982). Nigeria: Its petroleum geology, resources and potentials. (1) 176, (2) 238.Graham and Trotman, London, U.K.

[10] Evamy, B.D., Haremboure. J., Kamerling, P., Knaap, W.A., Molloy, F.A., and Rowlands P. B. (1978). Hydrocarbon habitat of Tertiary Niger Delta. American Association of Petroleum Geologists Bulletin. v. 62.

[11] Knox, G.J., and Omatsola, E.M., 1989. Development of the Cenozoic Niger Delta in terms of the 'Escalator Regression' model and impact on hydrocarbon distribution. In: van der Linden, W.J.M., Cloetingh, S.A.P.L., Kaasschieter, J.P.K., van der Graff, W.J.E., Vandenberghe, J., van der Gun, J.A.M. (Eds.), Proceedings KNGMG Symposiums on Coastal Lowlands, Geology and Geotechnology. Kluwer Academic Publishers, Amsterdam, pp. 181-202.

[12] Corredor, A., Lessenger, M.A., Capentino, P. (2005) Comparative source rock evaluation of opuama channel complex and adjacent producing areas of Niger Delta, Am. Assoc. Pet. Geol. Bull. 2 (6) 1027.

[13] Short, K. C., and Stauble, A. J. (1967). Outline of geology of Niger Delta, AAPG Bull 51: 761-779.

[14] Stacher, P. (1995). Present Understanding of the Niger Delta hydrocarbon habitat. In: Oti, M.N. and Postma, G.(eds.), Geology of Deltas,Rotterdam ,A.A .Balkema. pp. 257-267.

[15] Avbovbo, A. A. (1978). Tertiary Litho-stratigraphy of Niger Delta. American Association of Petroleum Geologists Bulletin, 62, 295-300.

[16] Espitalié, J., Laporte, J. L., Madec, M., Marquis, F., Leplat, P., Paulet, J. and Boutefeu, F. (1977) Méthode rapide de caractérisation des roches mères, de leur potentiel pétrolier et de leur degré d'évolution. Rev. Inst. Français du Pétrole, 32, 23-42.

[17] Peters, K.E. (1986). Guidelines for evaluating petroleum source rocks using programmed pyrolysis. AAPG Bull., 70, 329.

[18] Tissot, B.P.,and Welte, D.H. (1984) : Petroleum Formation and Occurrence. Springer-Verlag, New York. 699.

[19] Durand, B. (1980). Kerogène insoluble organique matter from sedimentary rocks. IFP, Paris.
[20] Peters, K.E., Moldowan, J.N. (1993). The Biomarker Guide: Interpreting Molecular fossils in Petroleum and Ancient sediments prentice Hall. Englewood cliffs, New Jersey.

[21] Deroo, G., Espitalie, J., Marquis, F. (1986). La pyrolyse ROCK EVAL et ses applications, IFP, Paris.

[22] Peters, K.E., and Cassa, M.R. 1994. "Applied Source Rock Geochemistry in Magoon, L. B, and W. G. Dow, eds., 1994, The petroleum system - from source to trap: AAPG Memoir 60.

[23] Nwachukwu, J.I., Chukwura, P.I. (1986). Organic matter of Agbada Formation, Niger Delta, Nigeria. American Association of Petroleum Geologists Bulletin 70, 48-55.

[24] Magoon, L. B. and Valin, Z. C. (1994). Overview of petroleum system case studies. In: The Petroleum System - From Source to Trap (L. B. Magoon and W. G. Dow, eds.), American Association of Petroleum Geologists, Tulsa, OK, pp. 329-38.

[25] Asadu, A. N., Omo-Irabor, O.O., and Ibe, K. A. (2015). Source Rock Characterisation of AGBADA Formation in Well Z, Offshore, Niger Delta, Nigeria. International journal for research in emerging science and technology. Vol. 2, 92-100.

[26] Ogbesejana, A.B., Bello, O.M., Uduma, A.U. (2018). Characterization of Source Rocks from Off-shore Niger Delta Basin. J. Appl. Sci. Environ. Manage. Vol. 22 (3), 356 -361.

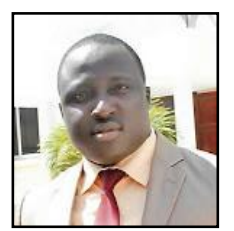

Kouadio Koffi Eugene is from Bongouanou (Cote d'Ivoire) born on $18^{\text {th }}$ July 1980. He holds Engineer degree in Petroleum Engineering from St Petersburg State Mining Institute, Russia. He also holds MSc in Petroleum Geosciences and Reservoir Engineering from Institut National Polytechnique de Lorraine, Nancy, France.

He is currently a PhD student in Petroleum Geosciences at the World Bank African Centre of Excellence, Centre for Oilfield Chemicals Research (ACECEFOR), University of Port Harcourt, Nigeria. He works as LecturerResearcher in the department of Earth Science and Mineral Resources at Institut National Polytechnique Félix Houphouet-Boigny of Yamoussoukro (INP-HB), Côte d'Ivoire. 